\title{
REFLECTION OF TEACHER'S INTERPERSONAL SKILL: DESCRIBING THE QUALITY OF AN EFFECTIVE TEACHER
}

\author{
Hastowohadi \\ Email: hastowohadi@gmail.com \\ University of 17 Agustus 1945 Banyuwangi
}

\begin{abstract}
There are six characteristics that can not be taught, only modeled, they are: Caring, Fairness and Respect, Attitude toward the Teaching Profession, Social Interaction with Students, Promotion of Enthusiasm and Motivation for Learning, Reflective Practice. The aspect of teacher as a person is only one of six aspects that should be modeled and demonstrate to the students. But, this aspect is going to be left by teachers in this era. It will be monotonous teacher as a leader and messenger in holding the whole class of teaching learning activity. Furthermore, in this research, the writer wants to explore and find out what are actually the problems of this issue. The research was done in SMK Visi Global in Banyuwangi and took 6 teachers as object of research. The writer used descriptive qualitative and describing the phenomenon of this. Indeed, the result was Fairness and Respect, Attitude toward Teaching Profession, Enthusiasm and Motivation for Learning, and Reflective Practice got above average but Caring, Social Interaction with Students got below average. This issue described that the teachers in SMK Visi Global were not enlightened by good teacher as a person and it would be ineffective for the school and students itself. It can be concluded that preparing teacher's personality is unavoidable for professional teacher, in this era or future.
\end{abstract}

Keywords: Teacher's Personality, Effective Teacher, Interpersonal Skill.

\section{INTRODUCTION}

Teacher plays significantly role to shape students' character and achievement in or out of class. Most teachers do not want to be just good teachers, they want to be great teachers (NWREL, 2001). An idea is about showing off the ability and capability of a figure like teachers that being very good example wherever he or she is. Teachers can grow significantly with their background of academic, but today, 
teachers should empower their in repertoire of instructional, management, and assessment knowledge with skills. Teachers should create meaningfully teaching practice and teaching personality to create meaningfully students' experiences. Teachers should improve their effectiveness in delivering high quality, productive learning experiences and also approach to students. A credible teacher portrays those qualities as q continuum part of professionally instructor being in-outside of class.

Are you a good teacher? This question appears in our mind continually, every second. It sometimes difficult to answer because it is too broad. What is the limitation should be noticed, and do we think that it should be answered comprehensively. Let discuss one by one. Good teacher is not merely someone who can teach instructively and smart. This part is only cognitive aspect of teacher but how come with affective aspect. It has been argued for many times that teacher should have cognitive aspect, moreover affective aspect is exception of educational progress. It is not really important, indeed, for teacher; teacher should not have this particular aspect. On contrary, it is really dangerous that teacher avoids that aspect. Either instructionally in class but also interpersonal skill of being teacher should be implemented in educationally circumstance and socially. A teacher's interpersonal skills are the basis for creating strong working relationships and positive classroom climate for learning (Wubbels, Levy, \& Brekelmans, 1997).

Teacher should be care, fair, respect, good attitude toward teaching profession, social, enthusiastic, and motivated. These aspect are regarding to professional teacher nowadays. Teachers should be care to students whom either very good academic achievement or not. These types of students could be taught fairly and respectfully. Teacher is not only model in class but should be modeled out of class with high tension of social approach. The last, teacher should enhance enthusiasm and motivation toward his background of academic and competencies.

These qualified teacher personality refer to teacher's quality and it needs to hold up frequently. 
Lastly, professionalism is teacher's personality toward teacher attitude in or outside of school area. Teacher can show their ability at skill or soft skill. Teacher as a good person, furthermore, cognitively shows good aspect to students while students feel enjoyable toward his teaching atmosphere and close to comfortable feeling. These characteristics of being teacher is cannot be taught, but modeled. The teacher as a person is caring, fairness and respect. His attitude should close to his profession, social interaction, motivation and enthusiasm for practice and reflective learning around students.

\section{Teacher as a person}

1. Self-Assessing key quality

Teacher should adjust into surroundings and adapt many things including those aspects of interpersonal skills. Teacher should assess himself toward his approach to students interactively. How would be he like when he interacts with pupils, how he would solve problem of students by that time intensively. So, teacher should assess more than those questions and it would be broader at the same time. Being a teacher is not only occurs on students but also himself. How would he overcome the problem to not being tangle of teaching in class. This should be considerations of good teacher.

2. Building bridges to solve dilemmas

Communication is very important aspect to correct situation that teacher should manage well. Teacher needs to build up bridges from himself to pupils; every single problem should be tackled seriously and intensively between him and pupils. A good communication means he tries to continually build direct or indirect communication without any obstacles. It has some strategies to assist in achieving the desired outcome. They are:

a. Have students write their autobiographies as the topic for the 7 grade research paper. They could include interviews, etc.

b. Do an interest inventory to see what students like

c. Have a highlights board in the room where students can share accomplishment / announcements.

d. Use homeroom time to talk with students 
e. Try to stay after school one day every week to help students or watch an after-school sporting/band/drama event.

f. Invite students to have lunch chats with teacher in small groups.

3. Caring, Fairness, Respect

These aspects should be bundled altogether. It inserts towards teacher's personality as a unity. Being care, fair, respect to him, students, and environment as well as possible. It will humanize teacher as a person to engage more besides his teaching skill aspect. In respect role, every actions taken by teacher should consider discipline, especially involving fair not unfair. Students want to see "right" triumph and be rewarded, while "wrong" are punished. Respect is a cornerstone of classroom's foundation. Respectful teacher always demonstrate respect in various ways and environments. Equitable treatment of students, regardless of race, gender, and other differences, is vital (Peart \& Campbell, 1999). Indeed, teacher incorporates these treatments to students as well as teaching method in class, unless they can achieve mutual understanding regarding to good teaching atmosphere. Effective teacher thinks that students is his family and partner so he uses to recognize and aware of him. Based on (Rockwell, Andre, \& Hawley , 1996) stated that depending on the families' desired level of involvement, the teacher responds in a variety of ways from simple communication to collaboration. Furthermore, teacher should communicate intensively with family to build up good understanding to educate students and their awareness. In fact, effective teachers have been found to correspond more frequently with parents (Taylor, Pearson, Clarks, \& Walpole 1999). Effective teachers should engage students as his partners, respecting them, their families and engage them to ongoing journey to school. It will support teacher to raise meaningfully teaching-learning process beautifully. The areas of caring are:

a. Listening

b. Expressing feeling

c. Knowing students on personal level 
d. Demonstrating patience, honesty, trust, humility, hope, and courage

e. Accommodating students' level

f. Using a considerate tone of voice and manner

g. Paying attention to each student

h. Showing receptive body language

i. Valuing students' input in problem solving (Collinson et al.; Deiro, 2003; Ford \& Trotman, 2001; Thomas Montgomery, 1998)

Teachers can be valuable in the process which has been mentioned above. Those aspects hopefully engage teaching learning atmosphere are going to be expected as teaching professionalism. It aims to be holding aspects as a unity.

\section{RESEARCH QUESTIONS}

To conduct this research, researcher needs to find out questions that are eligible to answer the problem from phenomenon happened during the research. In finding the question, researcher found that there are two urgent questions need to be answered. They are:

1. What are the strengths and weaknesses of the teacher?

2. How does the strengths and weaknesses affect his teaching?

These particular questions are referring to the condition of teacher when the research conducted at school.

\section{QUALITIES OF EFFECTIVE TEACHER Role of Reflective Practice}

Reflection is the just the way teacher portray themselves in a mirror then improve the weaknesses of theirs. It is a part of being effective teacher as a professional practice. Reflection is the 'supervisor' that encourages teachers to continue what worked and correct what isn't working (Harris, 2003 p. 39). 


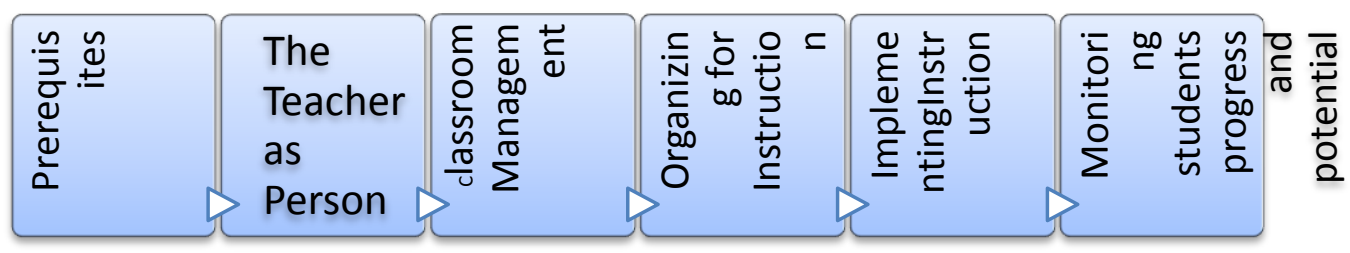

\section{RESEARCH METHOD}

The researcher used descriptive qualitative to come up the research problems on teacher. The researcher tried to find the phenomenon happened during the time of being observed. Indeed, qualitative research does take time, involves ambitious data analysis, results in lengthy reports, and does not have firm guidelines (Creswell, 2007).

\section{FINDING AND DISCUSSION}

In taking the data, the researcher took seven object of research. They were working everyday at school and dedicate themselves in developing students' progress in or out of class. The researcher used descriptive qualitative method to find out phenomenon happened with teachers. In conducting the research, the researcher used questionnaire to measure that they are in charge to take care of their students. There are 27 questions delivered to teachers with four thick level from 'seldom' to 'always'. These questions were designed by James $\mathrm{H}$. Stronge and friends.

It was found the data from SMK Visi Global in Banyuwangi that the teachers were significantly good in personality but in one case was exception. One point here was about interaction with students which was under expectation. It was under average that raised one poin eighty seven was the same as 'rarely'. The next second position from beneath was showed two point seven was the same as 'sometimes'. The three more points were significantly good that raised 'usually'. It means that it was not balance to be teacher as interpersonal skill. Whereas the teachers work every day and the rest of other teachers whom do not research on this do not work every day; the numbers of other teachers are higher than teachers who work at school every day or called regular teacher. In other word, caring aspect that shows high point in this case, therefore, other aspects show bad point. Indeed, it is 
less hope of being teacher as a person. It can be assumed that most of teachers there were not quite professional to be teachers as interpersonal skill.

\section{CONCLUSION}

From the explanation above, it can be assumed that the teachers were not quite balance as interpersonal skill with six teachers as the object of research. These imbalance factors can influence the whole process of shaping students to be the product of educational system. Moreover, students need such attention toward their competence in absorbing the material well. On the other hand, teachers could not influence theirs students; teachers cannot support and give students raise learning process in or out of class. Students vivid life based on teachers' personality in handling students get score and can survive as students' soft skill. Not only students can achieve soft skill but also teacher's source or as model of good person must achieve that skill first. Indeed, teachers as model of good figure should give students good impact not only on score but also soft skill to students. Teachers regard to human as educator and mentor as description of good personality.

Here are some suggestions to Teachers, Next Researchers, School for improving good standard on educational system in the future. They are:

1. Teachers: hopefully teachers should learn from this research and improve by themselves to gain good teachers as persons.

2. Next researcher: I wish that next researcher will do other aspects besides teacher as a person to complete qualities of teacher.

3. School: I hope teachers could manage their teachers on this aspect carefully.

\section{REFERENCES}

Creswell, (2007) Designing and conducting mixed methods research. Thousand Oaks. CA:Sage

Harris, (2003) p. 39 An Andragogical Model; Learning through Life Experiences. Kappa Delta Pi Record, 40 (1), 38-41. 
NWREL, (2001) Understanding and Supporting Teacher Renewal. Retrieved October 20, 2003, from http://www.nwrel.org/nwreport/jan03/motivation.html.

Peart \& Campbell, (1999) At Risk Students' Perception of Teacher Effectiveness. Journal for a Just and caring Education, 5 (3), 269284.

Rockwell, Andre, \& Hawley, (1996) Parents and Teachers as partners: Issues abd challenges. Forth Worth: Hartcourt Brace College.

Taylor, Pearson, Clarks, \& Walpole (1999) Center for The Improvement of Early Reading Achievement: Effectice schools/accomplished teachers. The Reading Teacher, 53 (2), 156-159.

Wubbels, Levy, \& Brekelmans, (1997) Paying attention to relationship (electronic version). Educational Leadership, 54 (7), 82-86. Retrieved November 12, 2003, from http://pdonline..acsd.org/pd_online/classmanage/e1199704 _wubbels.html. 